\title{
Oviposition and development in the glass frog Hyalinobatrachium orientale (Anura: Centrolenidae)
}

\author{
Mohsen Nokhbatolfoghahai', Christopher J. Pollock², and J. Roger Downie ${ }^{2}$ \\ ${ }^{1}$ Biology Department, Faculty of Science, University of Shiraz, Shiraz 71345, Iran. E-mail: nokhbeh@hotmail.com. \\ 2 School of Life Sciences, Graham Kerr Building, University of Glasgow, Glasgow G12 8QQ, UK. \\ E-mail: roger.downie@glasgow.ac.uk.
}

\begin{abstract}
Oviposition and development in the glass frog Hyalinobatrachium orientale (Anura: Centrolenidae). Oviposition and external embryonic developmental features are described in the Tobago glass frog, Hyalinobatrachium orientale. Egg clutches are nearly always laid on the undersides of leaves (one exception); usually leaves of Heliconia sp. are used, but Philodendron and palms may be used in the absence of Heliconia. Clutches contain $28.0 \pm$ 5.3 eggs (mean $\pm \mathrm{SD}$ ) and eggs are $1.86 \pm 0.11 \mathrm{~mm}$ in diameter. The behavior of one amplectant pair was followed for more than five hours; the pair rotated several times around a small area of the leaf depositing eggs in a tight spiral formation. External embryonic features were observed by scanning electron microscopy. Surface ciliation is extensive up to the time of hatching when it is lost; external gills are short and a cement gland is absent. Hatching gland cells were detectable on the anterodorsal surface of the head from Day 4 after deposition and persisted until at least Day 10, and hatching occurred between Days 9 and 16. During this period, progressive development in tail length, surface pigmentation, intestinal coiling, and oral disc features was observed. Post-hatching larvae reared for six weeks grew $37 \%$ in length and tripled in weight, but remained at Gosner Stage 25.
\end{abstract}

Keywords: amphibians, embryonic development, glass frogs, oviposition, Tobago, West Indies.

\footnotetext{
Resumo

Ovipostura e desenvolvimento na perereca-de-vidro Hyalinobatrachium orientale (Anura: Centrolenidae). Descrevemos aqui características da ovipostura e do desenvolvimento embrionário externo da perereca-de-vidro de Tobago, Hyalinobatrachium orientale. Os ovos são quase sempre depositados na superfície abaxial das folhas (com uma exceção). Geralmente, são usadas folhas de Heliconia sp., mas, na ausência destas, podem ser usadas folhas de Philodendron sp. e de palmeiras. As desovas contêm $28,0 \pm 5,3$ ovos (média \pm DP) e os ovos possuem diâmetro de $1,86 \pm 0,11 \mathrm{~mm}$. $\mathrm{O}$ comportamento de um casal em amplexo foi acompanhado por mais de cinco horas; o casal girou
}

Received 14 November 2014.

Accepted 22 April 2015.

Distributed June 2015. 
diversas vezes em torno de uma pequena área da folha, depositando os ovos em uma formação espiral apertada. As características embrionárias externas foram observadas por microscopia electrônica de varredura. A ciliação é extensa até o momento da eclosão, quando é perdida; as brânquias externas são curtas, e não existe uma glândula de cemento. Células glandulares de eclosão foram detectadas na superfície anterodorsal da cabeça a partir do dia Dia 4 após a ovipostura e persistiram até pelo menos o Dia 10, e a eclosão ocorreu entre os Dias 9 e 16. Durante esse período, foi observado o desenvolvimento progressivo do comprimento da cauda, da pigmentação superficial, do enovelamento do intestino e das características do disco oral. Após a eclosão, larvas criadas por seis semanas cresceram $37 \%$ no comprimento e tiveram seu peso triplicado, mas permaneceram no estágio 25 de Gosner.

Palavras-chave: anfíbios, desenvolvimento embrionário, Índias Ocidentais, ovipostura, pererecasde-vidro, Tobago.

\section{Introduction}

Frost (2014) listed 148 species of glass frogs of the family Centrolenidae, all of which inhabit Neotropical rainforests and deposit their eggs as gelatinous masses on leaves overhanging streams. In the 30 species of Hyalinobatrachium, egg masses usually are laid on the undersides of leaves, where they apparently are guarded by males (Villa 1984, Vockenhuber et al. 2009, Delia et al. 2010, Lehtinen and Georgiadis 2012, Murphy et al. 2012, Valencia-Aguilar et al. 2012, Delia et al. 2014, Lehtinen et al. 2014). In most other centrolenid genera, eggs are deposited on the upper sides of leaves and there is no evidence of parental care (Hoffmann 2010), except for female care in Ikakogi tayrona (Guayasamin et al. 2009).

Reports on embryonic development in glass frogs are scarce. Hoffmann (2004) described some aspects of development in Hyalinobatrachium pulveratum (= Teratohyla; Frost 2014), which were supplemented by Hawley (2006). Delia et al. (2014) summarized the developmental sequence in H. fleischmanni. Salazar-Nicholls and Del Pino (2014) described embryonic development in another two species of glass frog. However, none of these authors based their observations on high-resolution microscopy as have Nokhbatolfoghahi and collaborators, who have used scanning electron microscopy (SEM) to describe the external features of a wide range of anuran embryos and larvae. Among the features described are: surface ciliated cells (Nokhbatolfoghahai et al. 2005, 2006), cement glands (Nokhbatolfoghahai and Downie 2005), hatching gland cells (Nokhbatolfoghahai and Downie 2007), and external gills (Nokhbatolfoghahai and Downie 2008, Nokhbatolfoghahai et al. 2013). These authors often noted that external embryonic features differ markedly between embryos developing in water and those undergoing some kind of terrestrial development. Because glass frogs are terrestrial arboreal developers, their embryonic and larval features are of interest. We report here on oviposition, and embryonic and early larval development in the Tobago glass frog Hyalinobatrachium orientale Hardy, 1984. Castroviejo-Fisher et al. (2008) established that $H$. orientale inhabits both Tobago and the eastern part of Venezuela's Cordillera de la Costa and Jowers et al. (2014) suggested that the Tobago population is distinct enough to merit subspecies designation, as suggested by Hardy (1984).

\section{Materials and Methods}

Egg clutches of Hyalinobatrachium orientale were found in Tobago, West Indies, during July 2012, June-August 2013, and June 2014. Most observations were made along three rivers in secondary forest in northern Tobago: Doctor's River $\left(11^{\circ} 18.7^{\prime} \mathrm{N}, 60^{\circ} 32.4^{\prime} \mathrm{W}\right.$, elevation $\left.13 \mathrm{~m}\right)$; 
Hermitage River $\left(11^{\circ} 18.8^{\prime} \mathrm{N}, 60^{\circ} 34.5^{\prime} \mathrm{W}, 18 \mathrm{~m}\right.$ a.s.1.); and an unnamed river $\left(11^{\circ} 17.5^{\prime} \mathrm{N}, 60^{\circ} 38^{\prime}\right.$ W, $212 \mathrm{~m}$ a.s.1.). A few clutches and frogs also were observed along a small stream adjacent to Spring Trail on the Main Ridge Forest Reserve ( $11^{\circ} 17.2^{\prime} \mathrm{N}, 60^{\circ} 5.7^{\prime} \mathrm{W}, 384 \mathrm{~m}$ a.s.1.). The positions of calling males and amplectant pairs were determined at night, and the following morning, leaves were searched for the presence of egg clutches and guarding males. In one case, the complete sequence of oviposition was observed in situ and recorded by means of photographs. The progress of clutch development was followed in situ by returning on up to 15 successive days to re-photograph clutches. All photographs were taken using a Nikon D5100 DSLR with a Nikkor 40-mm macro lens. In addition, eight egg clutches were collected the day after oviposition or some days later by cutting off the part of the leaf holding the eggs and returning it to the laboratory for observation.

The first three clutches collected (in 2012) were incubated at ambient temperature in the laboratory $\left(28^{\circ} \mathrm{C}\right)$ by suspending the leaf above water and misting the eggs twice a day. One clutch was at a late stage of development and larvae soon hatched into the water; another two were at early stages and did not develop well, despite using the method recommended by Rada et al. (2007). Three early and two later stage clutches collected in 2013 and 2014, respectively, were incubated in closed petri dishes, egg side uppermost, leaf down; each clutch was moistened with a drop or two of stream water twice a day. Development through to hatching occurred successfully under this regimen.

In 2013, embryos, along with their jelly capsules from each clutch were sampled daily until hatching and fixed in $2.5 \%$ glutaraldehyde in phosphate buffer for at least five hours. The specimens were rinsed and stored in $0.1 \mathrm{M}$ phosphate buffer ( $\mathrm{pH} 7.4$ ) at $5^{\circ} \mathrm{C}$ until processing; see Nokhbatolfoghahai et al. (2005) for full methodology. Jelly capsules were removed; embryos were measured with dissecting microscope with eyepiece scale, and then photographed and staged using Gosner (1960) and Nieuwkoop and Faber (1975) for later stages. Specimens were rinsed in several changes of buffer, postfixed in $1 \%$ osmium tetroxide for one hour, washed in distilled water and then immersed in $0.05 \%$ aqueous uranyl acetate in the dark for one hour. After a brief distilled water rinse, specimens were dehydrated in an acetone series then critical point dried for $40 \mathrm{~min}$, coated with gold using a Polaron SC 515, and examined with a JSEM 6400 scanning electron microscope. Images were examined at a range of magnifications $(\times 24, \times 3200)$ and recorded by Imageslave for Windows (Meeco Holdings, Australia). In 2014, three embryos from each clutch were fixed in formalin soon after collection; the remainder were incubated as described above until the first embryos hatched, when further samples were fixed. When hatching was completed, the embryos were kept in water without food for two days before samples were fixed. Formalin-fixed specimens were measured, photographed, and processed for SEM.

In addition, 10 hatchlings from one 2014 clutch and five from another were transferred to two growth tanks. These were plastic basins 43 $\mathrm{cm}$ diameter and $23 \mathrm{~cm}$ deep; we covered the bottom of each with gravel and small stones taken from a local stream and filled each to a depth of $12 \mathrm{~cm}$ with dechlorinated tap water. The basins were placed close to a slatted window to provide shaded natural light and the water was aerated continuously by aquarium pumps attached to air stones. Each tank received a pinch of tropical fish food flakes every second day. After six weeks, the rocks and gravel were removed from the basins. Surviving larvae were recovered and lethally anaesthetised with Benzocaine, and preserved in formalin for examination.

Specimens were collected and exported under the Trinidad Government Wildlife Division's permit number 001741 . They are deposited in the University of Glasgow's Hunterian Zoology Museum, accession number GLAHM 1437. 


\section{Results}

All but one of the egg clutches that we observed $(N=28)$ were found on the undersides of leaves; the sole exception was a clutch deposited on the top of a leaf hanging vertically. Of 20 clutches followed in situ, $70 \%$ were on Heliconia sp. leaves, $20 \%$ on Philodendron sp., and $10 \%$ on unknown species of plants. At Spring Trail, the vegetation bordering the stream differs from that of the lowland rivers; Heliconia sp. is absent and egg clutches were located on the undersides of spiny palm leaves. The timing and activities of an amplectant pair are summarized (Table 1).

The 23 clutches observed at early stages (all in 2013) contained $28.0 \pm 5.3$ (mean $\pm \mathrm{SD}$; range 20-38) eggs. Eggs are $1.86 \pm 0.11 \mathrm{~mm}$ diameter (mean $\pm \mathrm{SD}, N=33$, all in one clutch); each clutch was surrounded by transparent jelly in a single-layered, close-packed spiral pattern.

The timing of embryonic development in the laboratory is summarized (Table 2). Development (from newly laid eggs to well-developed embryos) of a single clutch in the field, is depicted (Figure 1); hatching had not occurred by Day 16. SEM photographs of selected embryonic stages from late neurula onwards are illustrated (Figure 2). Hatching occurred between Days 9 and 16 in the field. Hatching in the laboratory occurred in Days 11-13 in one clutch and in another, all hatched on Day 12. The embryos remained at Gosner Stage 25 (undiscernable limb buds) during this period, but based on Nieuwkoop and Faber's (1975) developmental system, internal development proceeded and could be staged by, the degree of intestinal coiling. Three larvae kept in water without food for two days after hatching at Day 13 did not show significant further development.

From Stage 24 onward, the tail is about $70 \%$ of total length of the larva; it has narrow dorsal and ventral fins originating well posterior to the body. Superficial pigmented cells first appear on the dorsum and are absent on the tail and yolk sac at Day 5; pigmentation of body, dorsal yolk sac, and tail increases from Days 6-13 (Figure 3 ). The oral disc is not fully developed by Day 13. At Day 10, visible jaws and tooth rows are absent, but marginal papillae have formed; at Day 11, jaws are keratinized, but teeth are absent, although the tissue rows that will bear teeth have formed (Figure 4). Teeth are visible and keratinized on one anterior row and two

Table 1. Oviposition behavior observed in one amplectant pair of Hyalinobatrachium orientale.

\begin{tabular}{|c|c|}
\hline Time (h) & Activity \\
\hline $21: 30-21: 50$ & $\begin{array}{l}\text { Female with numerous eggs visible through body wall approaches calling male. } \\
\text { Male's call changes from short high pitched "peep"to a longer, more swooping sound. }\end{array}$ \\
\hline $21: 50$ & Male grasps female in amplexus. \\
\hline $21: 50-02: 30$ & $\begin{array}{l}\text { The amplectant pair occasionally move, rotating several times around a small area on the leaf: } \\
\text { this continues for almost four hours. }\end{array}$ \\
\hline $02: 30-02: 50$ & $\begin{array}{l}\text { The male disengages from the female, who moves about } 2 \mathrm{~cm} \text { away. The male resumes } \\
\text { moving around on top of the now-visible egg clutch; his hind limbs carry out spreading } \\
\text { movements on the egg clutch surface. }\end{array}$ \\
\hline 02:50-03.10 & $\begin{array}{l}\text { The male moves off the clutch, facing toward it. The female moves a little further away, } \\
\text { still on the leaf. }\end{array}$ \\
\hline $03: 15$ & The female is now further away, but the male remains close to the clutch. \\
\hline
\end{tabular}


Table 2. Time table of development for Hyalinobatrachium orientale NF - Nieuwkoop and Faber (1975).

\begin{tabular}{|c|c|c|c|}
\hline $\begin{array}{l}\text { Days after } \\
\text { fertilization }\end{array}$ & Gosner stage & Mean size $(\mathrm{mm})$ & Comment \\
\hline 1.0 & 11 & 2.0 diameter & Gastrulation \\
\hline 2.0 & 16 & 2.0 diameter & Neural tube \\
\hline 3.0 & $18 / 19$ & 4.5 length & Tail $52.5 \%$ of total length \\
\hline 4.0 & $19 / 20$ & 5.5 length & Tail $60.4 \%$ of total length \\
\hline 5.0 & 21 & 6.9 length & $\begin{array}{l}\text { Tail } 69.0 \% \text { of total length } \\
\text { First sign of pigmentation, dorsal }\end{array}$ \\
\hline 6.0 & $23 / 24$ & 8.1 length & $\begin{array}{l}\text { Tail } 71.6 \% \text { of total length } \\
\text { Dorsal body and yolk sac pigmented lightly }\end{array}$ \\
\hline 7.0 & $24 / 25$ & 8.9 length & Tail $71.5 \%$ of total length \\
\hline 8.5 & 25 & - & Can hatch \\
\hline 10.0 & 25 & 7.7 length & $\begin{array}{l}\text { Can hatch. NF Stage } 42-5 \\
\text { Tail } 66.8 \% \text { of total length }\end{array}$ \\
\hline 11.0 & 25 & 9.4 length & $\begin{array}{c}\text { NF Stage } 46 \\
\text { Tail } 70.5 \% \text { of total length } \\
\text { Conspicuously more pigmented than at } 10 \text { days. Jaws } \\
\text { keratinized but tooth rows only faintly pigmented }\end{array}$ \\
\hline 12.0 & 25 & 11.2 length & $\begin{array}{c}\text { NF Stage } 47 \\
\text { Tail } 70.1 \% \text { of total length } \\
\text { Dorsal pigmentation more complete than at } 11 \text { days. } \\
\text { Intestine contains pigmented material. Tooth rows more } \\
\text { pigmented than at Day } 11 .\end{array}$ \\
\hline 13.0 & 25 & 11.4 length & $\begin{array}{c}\text { NF Stage } 47 \\
\text { Tail } 70.1 \% \text { of total length } \\
\text { Dorsal pigmentation a solid line } \\
\text { Intestine contains pigmented material } \\
\text { Teeth now well developed: one anterior row, two posterior, } \\
\text { the first subdivided with a wide gap }\end{array}$ \\
\hline
\end{tabular}

posterior rows by Day 13 (Figure 4). A complex array of lateral line organs is present by this stage. Surface cell ciliation is first present at Day 2 (neural tube, Stage 16). The changing pattern of surface ciliation before hatching is charted (Table 3); most ciliated cells have disappeared by Day 10 , when only a few remain on the tail. External gills are rather simple and short, bearing a small number of short, flat secondary filaments with abundant ciliated cells. External gill measurements are presented (Table 4). There is no evidence of a cement gland. Surface cells with the morphology characteristic of hatching gland cells (i.e., small, highly microvillated cells interspersed among the larger micro-ridged pavement epithelial cells) are visible at Day 4 and are located on the anterodorsal surface of the head; they are still visible at Day 10 (Figure 5). 


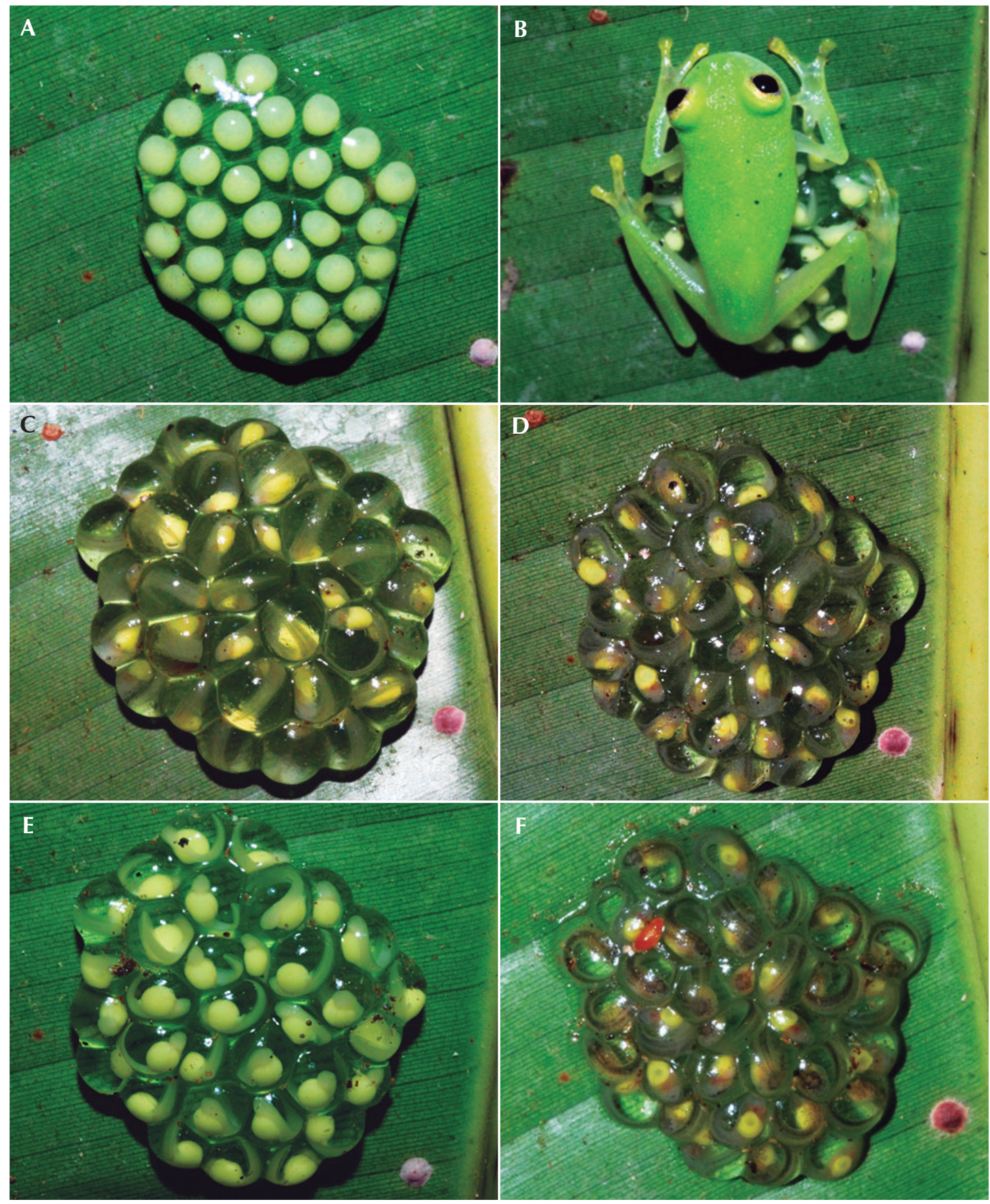

Figure 1. Development of a single clutch of Hyalinobatrachium orientale photographed in situ. (A) newly laid eggs; (B) male guarding the clutch, about 2 days after laying, Stage 18/19; (C) 4 days after laying, Stage 20; (D) 8 days, Stage 25; (E) 12 days, still Stage 25, tail longer, embryo more pigmented; (F) 16 days, still Stage 25, gut coiling pronounced, tail and body well pigmented. 


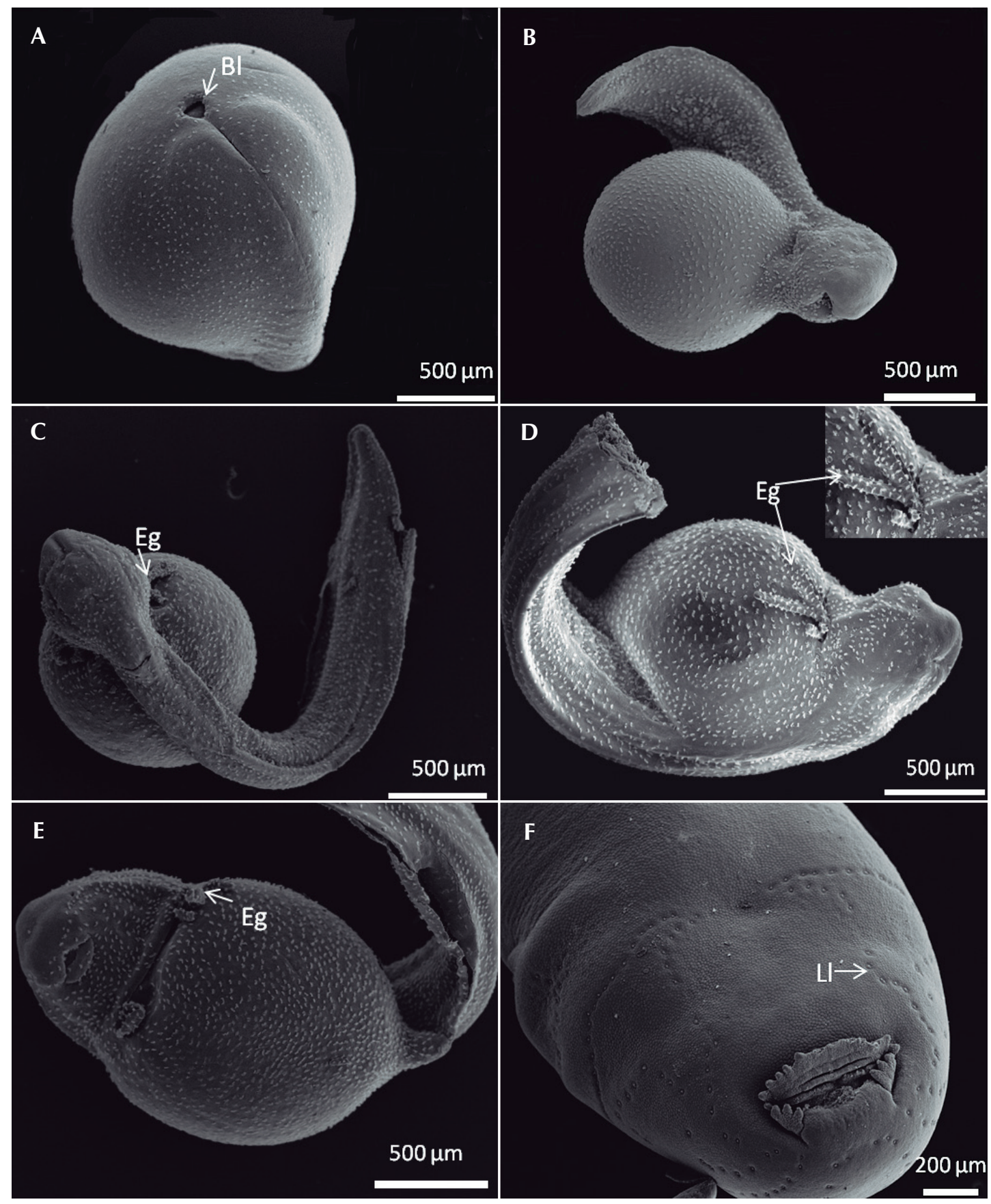

Figure 2. Development of Hyalinobatrachium orientale visualized by scanning electron microscopy. (A) late neurula, posterodorsal view; (B) Stage 18/19, lateral view; (C) Stage 20, dorsal view; (D) Stage 21, dorsolateral view; insert shows enlargement of external gill; (E) Stage 23, ventral view; (F) Stage 25, 13 days, ventral view of body showing lack of ciliated cells, development of oral disc, pattern of lateral line organs. B1, blastopore; Eg, external gill. LI, lateral line. 
Table 3. The changing pattern of surface ciliated cells in embryos of Hyalinobatrachium orientale Key: ND = not yet developed; $\mathrm{NA}=$ not applicable (structure deleted); Pf = primary gill filament; $\mathrm{Sf}=$ secondary filament; $-=$ not observed; $x x x x=$ ciliated cells dense; $x x x=$ cilated cells intermediate; $x x=$ ciliated cells dispersed; $x=$ ciliated cells very dispersed; $\mathrm{O}=$ ciliated cells absent (see Nokhbatolfoghahai et al. 2005 for criteria).

\begin{tabular}{|c|c|c|c|c|c|c|c|c|c|}
\hline \multirow{2}{*}{$\begin{array}{l}\text { Days after egg } \\
\text { deposition }\end{array}$} & \multirow{2}{*}{$\begin{array}{l}\text { Gosner } \\
\text { stage }\end{array}$} & \multicolumn{8}{|c|}{ Body region } \\
\hline & & $\begin{array}{l}\text { Dorsal } \\
\text { head }\end{array}$ & $\begin{array}{c}\text { Ventral } \\
\text { head }\end{array}$ & $\begin{array}{l}\text { Dorsal } \\
\text { trunk }\end{array}$ & $\begin{array}{l}\text { Ventral } \\
\text { trunk }\end{array}$ & Nostril & Tail & \multicolumn{2}{|c|}{ External gill } \\
\hline 1 & 11 & ND & ND & $\mathrm{O}$ & $\mathrm{O}$ & ND & ND & \multicolumn{2}{|c|}{ ND } \\
\hline 2 & 16 & $x x x$ & $\mathrm{v}$ & $x x x$ & - & ND & ND & \multicolumn{2}{|c|}{ ND } \\
\hline 3 & $18 / 19$ & - & $x x x x$ & - & $x x x x$ & $x$ & $x x x$ & $x x x x$ & Pf \\
\hline 4 & $19 / 20$ & $x x x / x x$ & $x x x x$ & $x x x x$ & $x x x$ & $x$ & $x x x x$ & $\begin{array}{l}x x x x \\
x x x x\end{array}$ & $\begin{array}{l}\text { Pf } \\
\text { Sf }\end{array}$ \\
\hline 5 & 21 & $\operatorname{xxxx}$ & $x x x x$ & $x x x x$ & $x x x$ & $x x$ & $x x x x / x x x x$ & $\begin{array}{l}x x x x \\
x x x\end{array}$ & $\begin{array}{l}\text { Pf } \\
\text { Sf }\end{array}$ \\
\hline 6 & $23 / 24$ & $x x x$ & $x x x x$ & $x x$ & $x x x x$ & $x$ & $x x x x / x x x$ & $\begin{array}{l}\text { NA } \\
x x x\end{array}$ & $\begin{array}{l}\text { Pf } \\
\text { Sf }\end{array}$ \\
\hline 7 & $24 / 25$ & $x x x x / x$ & $x x x$ & $x x$ & $x x x x$ & $x x x$ & $x x x x / x x$ & $\begin{array}{l}\text { NA } \\
x x x\end{array}$ & $\begin{array}{l}\mathrm{Pf} \\
\mathrm{Sf}\end{array}$ \\
\hline 8.5 & 25 & $\mathrm{x}$ & $x x$ & $x$ & $x x x$ & $\mathrm{O}$ & $x x x / x$ & & \\
\hline 10 & 25 & $\mathrm{O}$ & $\mathrm{O}$ & $\mathrm{O}$ & $\mathrm{O}$ & $\mathrm{O}$ & $x$ & & \\
\hline
\end{tabular}

After maintaining two tanks of hatchlings for six weeks (initially 10 tadpoles in one, five in the other), we recovered nine from one tank and none from the other. The mean total length of these larvae is $15.3 \pm 1.4 \mathrm{~mm}$ compared to 11.2 $\pm 0.2(N=10)$ for hatchlings and wet weights $0.03 \pm 0.007 \mathrm{~g}$ compared to $0.01 \pm 0.001(N=$ 9). Therefore, the larvae increased $36.6 \%$ in length and tripled in weight. However, none of the grown larvae had hind-limb buds; thus, externally, they remained at Gosner Stage 25. Oral discs were more fully developed than at Day 13, with a tooth row formula A2(2)/P3(1) following Altig and McDiarmid's (1999) system.

\section{Discussion}

The egg-clutch sizes we report are commensurate with those found by Lehtinen and Georgiadis (2012) - i.e., means of 28.0 and 28.3, respectively - and similar to those reported by Vockenhuber et al. (2009) for Hyalinobatrachium valerioi. One of the clutches we found was on the upper surface of a leaf; Vockenhuber et al. (2008) found $13 \%$ of $H$. valerioi clutches $(N=$ 164) on the upper sides of leaves, but noted that the arrangement of the leaves usually hid the clutches. Delia et al. (2010) reported clutches on the upper surface in one of 48 and nine of 40 


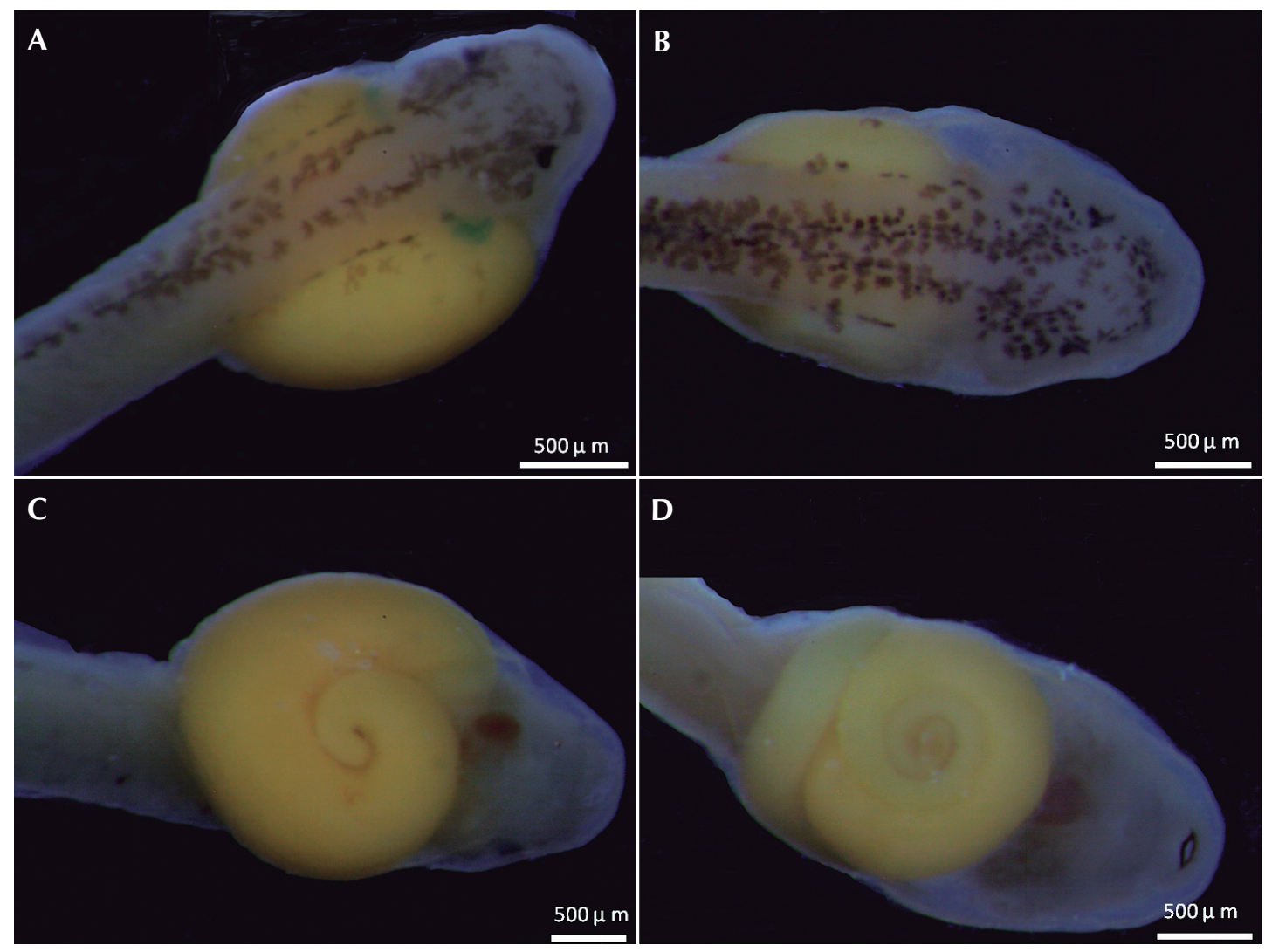

Figure 3. Light micrographs of anterior ends of hatchling Hyalinobatrachium orientale showing development of pigmentation and intestinal coiling. (A, B) dorsal views of body at Days 10 and 11, respectively; (C, D) ventral views at Days 10 and 11 , respectively.

Table 4. External gill dimensions in Hyalinobatrachium orientale from first appearance to final regression. Most measurements are Mean \pm SD based on 3 or 4 specimens.

\begin{tabular}{|c|c|c|c|c|c|c|}
\hline \multirow[b]{2}{*}{$\begin{array}{l}\text { Days after } \\
\text { egg } \\
\text { deposition }\end{array}$} & \multirow[b]{2}{*}{$\begin{array}{l}\text { Gosner } \\
\text { stage }\end{array}$} & \multirow[b]{2}{*}{ Length ( $\mu \mathrm{m})$} & \multicolumn{4}{|c|}{ External gill dimensions } \\
\hline & & & $\begin{array}{c}\text { Secondary } \\
\text { filament length } \\
(\mu \mathrm{m})\end{array}$ & $\begin{array}{c}\text { Primary } \\
\text { filament } \\
\text { diameter }(\mu \mathrm{m})\end{array}$ & $\begin{array}{l}\text { Secondary } \\
\text { filament } \\
\text { diameter } \\
(\mu \mathrm{m})\end{array}$ & $\begin{array}{c}\text { Gill length/ } \\
\text { snout-vent } \\
\text { length } \\
(\%)\end{array}$ \\
\hline 3 & $18 / 19$ & 187.5 & 0 & 162.5 & 0 & 11.1 \\
\hline 4 & $19 / 20$ & $190.4 \pm 29.9$ & $84.7 \pm 29.9$ & $50.5 \pm 0.7$ & $38.8 \pm 4.9$ & 11.9 \\
\hline 5 & 21 & $368.9 \pm 58.1$ & $252.7 \pm 55.6$ & $72.7 \pm 5.8$ & $59.6 \pm 7.0$ & 23.9 \\
\hline 6 & $23 / 24$ & $482.5 \pm 38.9$ & $406.1 \pm 128.6$ & 0 & $42.9 \pm 10.1$ & 27.3 \\
\hline 7 & $24 / 25$ & $238.1 \pm 29.4$ & $232.6 \pm 38.3$ & 0 & $48.7 \pm 7.6$ & 11.6 \\
\hline
\end{tabular}



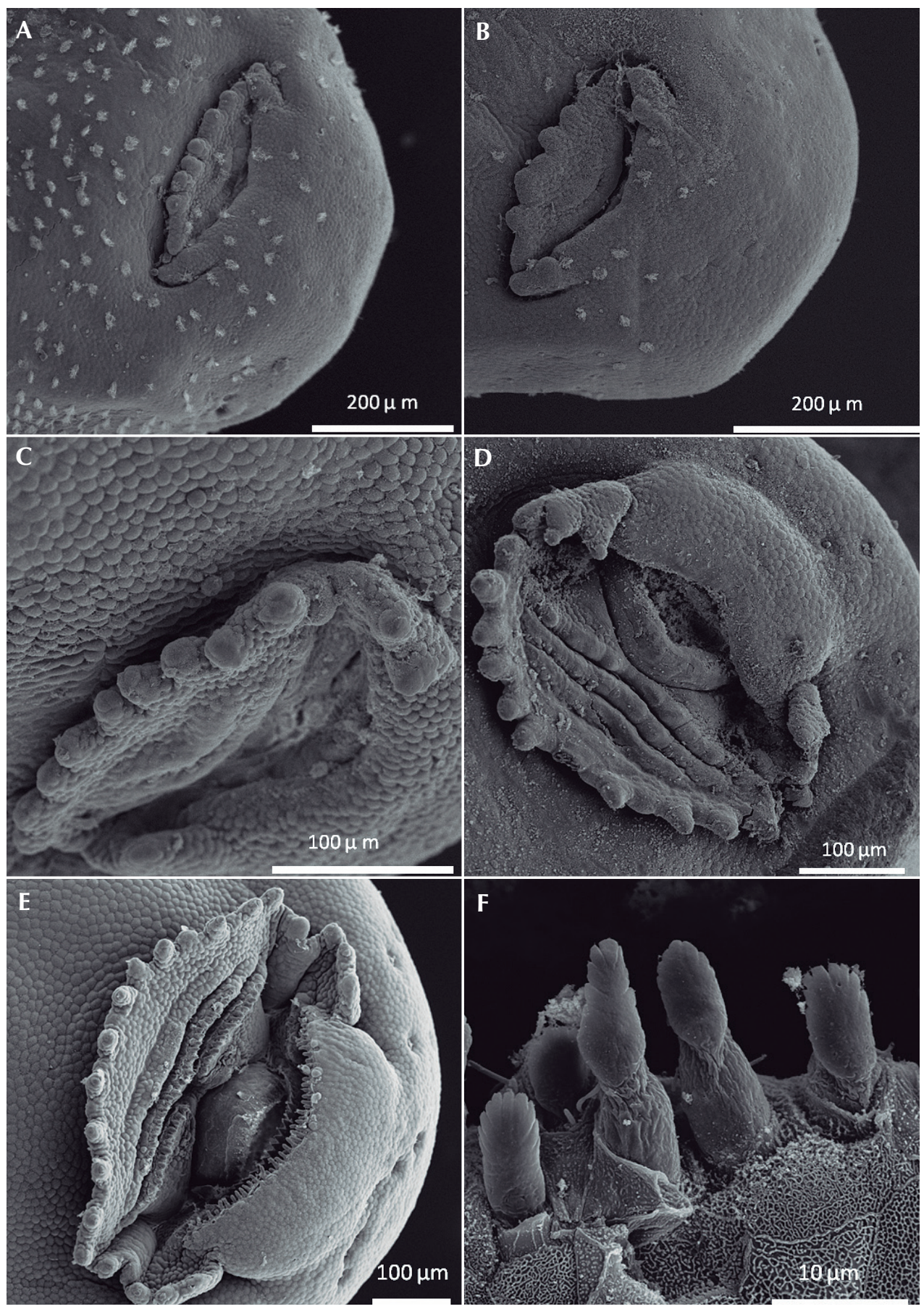

Figure 4. Scanning electron micrographs showing oral-disc development in Hyalinobatrachium orientale. (A) 8 days; (B) 9 days; (C) 10 days; (D) 11 days; (E) 13 days when tooth development is well advanced; (F) enlargement of first anterior tooth row shown in $\mathbf{E}$ to show presence of keratinized teeth. 


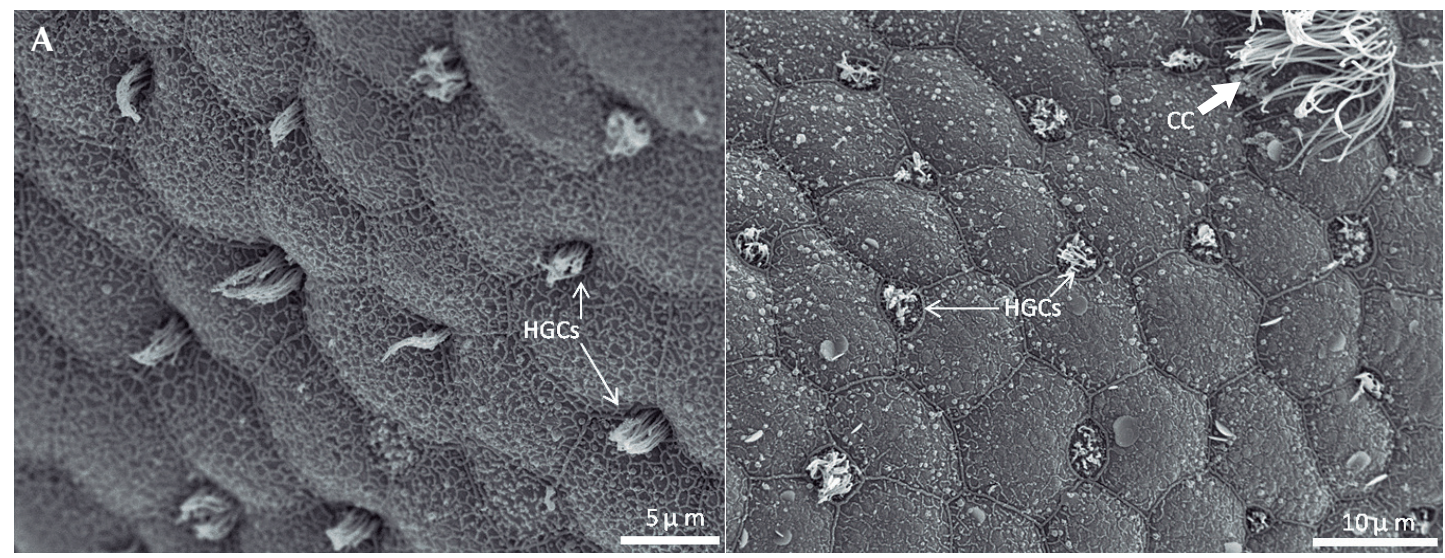

Figure 5. High-resolution scanning electron micrographs of anterodorsal surfaces of embryos of Hyalinobatrachium orientale showing presence of hatching gland cells (HGCs). (A) Stage 23, 6 days; (B) Stage 25, 10 days.

cases, respectively, in two regions in a study on H. fleischmanni. All but one of the clutches of $H$. orientale reported by Lehtinen and Georgiadis (2012) were on leaves of Heliconia sp. Where Heliconia sp. was common, we found most but not all, clutches on this type of leaf, but where absent, $H$. orientale oviposited on palm leaves.

The fullest account of glass frog amplexus and oviposition behavior is by Vockenhuber et al. (2008) in Hyalinobatrachium valerioi, in which amplexus lasts 5-7 hours, with the pair frequently moving around on the leaf. These authors thought that after the male and female separate, the male fertilized the eggs and spread them as a single layer on the leaf. In the case of $H$. orientale, it seems that the rotational movement of the amplectant pair arranges the eggs in a spiral on the leaf, but the leg movements of the male may have spread the sperm; more observations are needed to confirm these speculations. Guevara-Molina and Vargas-Salinas (2014) reported on amplexus and oviposition behavior in Nymphargus grandisonae, a glass frog that deposits eggs on the upper side of the leaf. They reported no rotational movements and found that the female remained for a time covering the eggs after clutch completion, in contrast to $H$. orientale.
Among the few previous accounts of glass frog embryonic development is Hawley's (2006) report on development of Hyalinobatrachium (= Teratohyla) pulveratum (Frost 2014) documented by daily or every-second day photographs of clutches, which allowed staging into approximate Gosner (1960) categories, but did not permit detailed morphological descriptions. Valencia-Aguilar et al. (2012) followed development in $H$. aureoguttatum and assigned Gosner stages, but did not describe their methodology; based on the features reported, it seems that they observed clutches without any microscopy. Hoffmann (2010) reported on tadpole morphology and growth in 13 species of Costa Rican glass frogs (six members of Hyalinobatrachium). His account includes descriptions of hatchlings and later stages, including some scanning electron microscopy of oral discs, but not of whole embryos. Delia et al. (2014) published a summary developmental sequence for $H$. Aleischmanni based on light microscopy and Gosner (1960) staging.

The timing of development in Hyalinobatrachium orientale and $H$. pulveratum are quite similar but $H$. aureoguttatum and $H$. fleischmanni seem to develop more slowly (Table 5). Developmental rate can be influenced by egg 
Table 5. Comparison of developmental timing in four glass frog species: Hyalinobatrachium aureoguttatum (ValenciaAguilar et al. 2012), H. pulveratum tobagoense (Hawley 2006), H. fleischmanni (Delia et al. 2014) and H. orientale (this study). Staging is approximate because of the different methods used in the three studies.

\begin{tabular}{lcccc}
\hline \multirow{2}{*}{ Gosner stage } & \multicolumn{4}{c}{ Days after oviposition } \\
\cline { 2 - 5 } & H. aureoguttatum & H. pulveratum & H. fleischmanni & H. orientale \\
\hline 11 & - & - & 2 & 1 \\
14 & - & 2 & - & - \\
17 & 4 & 3 & 4 & 2 \\
18 & 7 & 4 & - & 3 \\
$19-20$ & 9 & 5 & 8 & 4 \\
$22-23$ & 13 & 6 & - & 6 \\
$24-25$ & 17 & 11 & 12 & 7 \\
\hline
\end{tabular}

size and temperature with embryos developing more slowly in cooler temperatures (Duellman and Trueb 1994). Valencia-Aguilar et al. (2012) did not report egg size or incubation temperature; because their study sites were at higher elevations (350 $\mathrm{m}$ and $210 \mathrm{~m}$ ) than ours, the temperature may have been cooler. Hawley (2006) reported neither temperature nor egg size and Delia et al. (2014) did not report temperature, but their study site was at an altitude of $750 \mathrm{~m}$ (Delia, pers. comm.) and may have been relatively cool. The time taken to reach Stage 25 is the greatest variable in the three studies because of the variation in hatching time, which we discuss later. As expected, surface ciliation was prominent during the embryonic stages, declining around Stage 25 (Nokhbatolfoghahai et al. 2005) but, surprisingly, the nostrils were poorly ciliated compared to most other species we have observed.

External gills were unexpectedly poorly developed both in number of secondary filaments and filament dimensions. We found that embryos of other species developing in air to late stages at hatching (such as Phyllomedusa trinitatis, Mannophryne trinitatis) have long multi-branched gills at their maximal stages (Nokhbatolfoghahai and Downie 2008; Nokhbatolfoghahai et al. 2013). The poor development of the external gills in Hyalinobatrachium orientale may be related to the relatively slow development of these embryos.

The absence of a cement gland is not unexpected because Hyalinobatrachium orientale hatches and enters the aquatic environment at a late stage of development. The cement gland is prominent in species that hatch in Gosner Stages 17-20 and that spend the time between hatching and full development of the operculum stuck to a surface by means of cement gland mucus (Nokhbatolfoghahai and Downie 2005, Downie and Nokhbatolfoghahai 2006).

We identified cells that seemed to be hatching gland cells as early as Day 4 and as late as Day 10 of development. This does not mean that these cells were actively secreting throughout this period; a more experimental approach is needed to determine this. Lehtinen and Georgiadis (2012) noticed that at Stage 25 if the egg capsules were prodded, they hatched "explosively." This is reminiscent of hatching in other terrestrially developing eggs such as those of 
Phyllomedusa trinitatis (Downie et al. 2013) in which the eggs swell with fluid at late stages and hatch when touched. As Lehtinen and Georgiadis (2012) suggested, explosive hatching may be an anti-predator device.

The stage and time at which hatching occurs in anurans varies. The time of hatching can be influenced by many factors related to survival such as flooding, dehydration, and predator attack (Warkentin 2011). Delia et al. (2014) found that embryos of Hyalinobatrachium fleischmanni hatch early if abandoned by attending fathers, but at a later stage when attended; attendance had no effect on development rate. In addition, when anuran eggs are in compact nests (such as floating foam, Downie 1993) or folded leaves (Downie et al. 2013) there can be a delay between hatching and emergence, which may relate to fitness by allowing more time for development before entering the aquatic environment.

In the laboratory, clutches hatched as early as 8.5 days after fertilization, and some individuals did not hatch until Day 13. In the field, one clutch did not hatch until Day 16. Delia et al. $(2013,2014)$ demonstrated that the main function of paternal attendance is egg hydration, and that in the absence of the male, hatching occurs early. In our experiments, we provided daily hydration, but laboratory-reared embryos hatched earlier than the latest we found in the field. The level of hydration we provided may have acted as a hatching stimulus, or perhaps the embryos could detect the difference between hydration provided by the father and our artificial provision. In terms of operculum development, embryos reached Stage 25 (completion of operculum; external gills regressed and covered) by 8.5 days. However, the oral disc was not well developed by this time, indicating that Gosner staging may not work well for these embryos. Even after 12 days, tooth rows were not fully developed. We applied Nieuwkoop and Faber's (1975) criteria for distinguishing the progression of gut coiling between 8.5 and 12 days. The length of the tail and amount of pigmentation are other features that increased from the time of first hatching to the latest hatching we observed.

Several studies have reported that once glass frog embryos have developed to the point that they are able to hatch, hatching can be delayed. For example, Hawley (2006) found a range of 1-10 days between first and last hatching in $H$. pulveratum, and Vockenhuber et al. (2008) reported that $H$. valerioi reached Stage 25 and could hatch after 9 days, but some did not hatch until Day 19. Delia et al. $(2013,2014)$ noted that H. fleischmanni reached Stage 25 in 11-14 days, and hatching occurred immediately or up to 11 days later.

Of these studies, only Delia et al. (2014) reported on the progress of development between the first and last hatching. Our results show that development of pigmentation, gut coiling, and the oral disc progress. Delayed emergence from egg to the external environment may be advantageous. For example, Downie (1993) showed that Engystomops pustulosus hatch at Stage 21, but once hatched, larvae may not emerge from their foam nests for up to $17 \mathrm{~h}$, at which time they are at Stage 23/24 and possibly more likely to survive than larvae that emerge at Stage 21. Whereas this may be an advantageous strategy for embryos hidden in foam nests, it might prove hazardous to glass frog larvae that are exposed. So why does delayed hatching occur in glass frogs? Delia et al. (2013) suggested that high levels of paternal care promote growth and development, leading to later hatching. Hawley (2006) and Vockenhuber et al. (2008) speculated that hatching is delayed until it rains, thereby ensuring that there is adequate water in the stream below; they further suggested that stream turbidity following heavy rains may protect the hatchlings from predatory fish. Although Warkentin (2011) showed that hatching plasticity in red-eyed treefrogs is related to predation threats to the nest, we have seen no evidence of this in glass frogs.

Our post-hatching glass frog larvae grew and developed slowly relative to other tropical anuran larvae we have observed. For example, 
Downie (2013) reported four species that reach metamorphosis in about 20 days. Slow development may be characteristic of glass frog tadpoles; Hoffmann (2010) reared some species nearly to metamorphosis and Hyalinobatrachium species required more than 200 days. Downie et al. (2015) have described the Tobago glass frog tadpole.

\section{Acknowledgments}

JRD and CJP acknowledge the assistance of the University of Glasgow, the Carnegie Trust for the Universities of Scotland and Amazonia in funding their work in Tobago. Several members of the University of Glasgow Tobago Expeditions 2013 and 2014 helped with fieldwork. Lyndsay Christie maintained the larval growth tanks and preserved the specimens. John Murphy collected our initial sample of eggs in 2012 and also commented on the manuscript, as did Rick Lehtinen.

\section{References}

Altig R. and R. W. McDiarmid. 1999. Body plan: development and morphology. Pp 24-51 in R. W. McDiarmid and R. Altig (eds.), Tadpoles: The Biology of Anuran Larvae. Chicago. University of Chicago Press.

Castroviejo-Fisher, S., J. C. Señaris, J. Ayarzagüena, and C. Vilà. 2008. Resurrection of Hyalinobatrachium orocostale and notes on the Hyalinobatrachium orientale species complex (Anura: Centrolenidae). Herpetologica 64: 472-484.

Delia, J., D. F. Cisneros-Heredia, J. Whitney, and R. Murrieta-Galindo. 2010. Observations on the reproductive behavior of a Neotropical glassfrog, Hyalinobatrachium fleischmanni (Anura: Centrolenidae). South American Journal of Herpetology 5: 1-12.

Delia, J. R. J., A. Ramírez-Bautista, and K. Summers. 2013. Parents adjust care in response to weather conditions and egg dehydration in a Neotropical glassfrog. Behavioral Ecology and Sociobiology 67: 557-569.

Delia, J. R. J., A. Ramirez-Bautista, and K. Summers. 2014. Glassfrog embryos hatch early after parental desertion. Proceeding of the Royal Society B 281: 2013-3237.
Downie, J. R. 1993. Functions of the foam in foam-nesting leptodactylids: the nest as a post-hatching refuge in Physalaemus pustulosus. Herpetological Journal 3: 3542.

Downie, J. R. 2013. How long do Trinidad's frogs take to reach metamorphosis? Living World, Journal of Trinidad and Tobago Field Naturalists' Club 2013: 54-56.

Downie, J. R. and M. Nokhbatolfoghahai. 2006. Presence and absence of the cement gland in foam-nesting leptodactylids (Anura: Leptodactylidae): implications for the transition to terrestrial development. Herpetological Journal 16: 77-81.

Downie, J. R., M. Nokhbatolfoghahai, D. Bruce, J. M. Smith, N. Orthmann-Brask, and I. MacDonald-Allan. 2013. Nest structure, incubation and hatching in the Trinidadian leaf-frog Phyllomedusa trinitatis (Anura: Hylidae). Phyllomedusa 12: 13-32.

Downie, J. R., M. Nokhbatolfoghahai, and L. Christie. 2015. The tadpole of the glass frog Hyalinobatrachium orientale tobagoense (Anura: Centrolenidae) from Tobago, West Indies. Herpetological Bulletin 131: 2123.

Duellman, W. E. and L. Trueb. 1994. Biology of Amphibians. Baltimore. Johns Hopkins University Press. 670pp.

Frost, D. R. (ed.). 2014. Amphibian Species of the World: an Online Reference. Version 6.0 (30 January 2014). Electronic Database accessible at: http://research.amnh.org/ herpetology/amphibia/index.html. American Museum of Natural History, New York, USA. Captured on 30 January 2014.

Gosner, K. L. 1960. A simplified table for staging anuran embryos and larvae with notes on identification. Herpetologica 16: 183-190.

Guayasamin, J. M., S. Castroviejo-Fisher, L. Trueb, J. Ayarzagüena, M. Rada, and C. Vilà. 2009. Phylogenetic systematics of glassfrogs (Amphibia: Centrolenidae) and their sister taxon Allophryne ruthveni. Zootaxa 2100: $1-97$.

Guevara-Molina, S. C. and F. Vargas-Salinas. 2014. Nymphargus grandisonae (red-spotted glassfrog): reproductive behaviour. Herpetological Bulletin 128: 29-30.

Hardy, J. D. 1984. A new subspecies of Centrolenella orientalis (Anura: Centrolenidae) from Tobago, West Indies. Bulletin of the Maryland Herpetological Society 20: 165-173.

Hawley, T. J. 2006. Embryonic development and mortality in Hyalinobatrachium pulveratum (Anura: Centrolenidae) of south-western Costa Rica. Journal of Tropical Ecology 22: 731-734. 
Hoffmann, H. 2004. Description of the previously unknown tadpole of Hyalinobatrachium pulveratum (Anura: Centrolenidae). Revista Biologia Tropical 52: 219-228.

Hoffmann, H. 2010. The glass frog tadpoles of Costa Rica (Anura: Centrolenidae): a study of morphology. Abhandlungen der Senckenberg Gesellschaft für Naturforschung 567: 1-78.

Jowers, M. J., R. M. Lehtinen, R. J. Downie, A. P. Georgiadis, and J. C. Murphy. 2014. Molecular phylogenetics of the glass frog Hyalinobatrachium orientale (Anura: Centrolenidae): evidence for Pliocene connections between mainland Venezuela and the island of Tobago. Mitochondrial DNA: 1-6. doi:10.3109/19401 736.2014 .880888

Lehtinen, R. M. and A. P. Georgiadis. 2012. Observations on parental care in the glass frog Hyalinobatrachium orientale (Anura: Centrolenidae) from Tobago, with comments on its natural history. Phyllomedusa 11: 7577.

Lehtinen, R. M., S. E. Green, and J. I. Pringle. 2014. Impacts of paternal care and seasonal change on offspring survival; a multiseason experimental study of a Caribbean frog. Ethology 120: 400-409.

Murphy, J. C., S. Charles, and J. Traub. 2012. Hyalinobatrachium orientale (oriental glass frog): male parental care. Herpetological Review 43: 118-119.

Nieuwkoop. P. D. and J. Faber. 1975. Normal Table of Xenopus laevis (Daudin). A Systematical and Chronological Survey of the Development from the Fertilized Egg Till the End of Metamorfhosis. Amsterdam. NorthHolland Publishing Company. 260 pp.

Nokhbatolfoghahai, M. and J. R. Downie. 2005. Larval cement gland of frogs: comparative development and morphology. Journal of Morphology 263: 270-283.

Nokhbatolfoghahai, M. and J. R. Downie. 2007. Amphibian hatching gland cells: pattern and distribution in anurans. Tissue and Cell 39: 225-240.

Nokhbatolfoghahai, M. and J. R. Downie. 2008. The external gills of anuran amphibians: comparative morphology and ultrastructure. Journal of Morphology 269: 11971213.

Nokhbatolfoghahai, M., J. R. Downie, A. K. Clelland, and K. Rennison. 2005. The surface ciliation of anuran amphibian embryos and early larvae: patterns, timing differences and functions. Journal of Natural History 39: 887-929.

Nokhbatolfoghahai, M., J. R. Downie, and V. Ogilvy. 2006. Surface ciliation of anuran larvae: persistence to late stages in some species but not others. Journal of Morphology 267: 1248-1256.

Nokhbatolfoghahai, M., J. R. Downie, and L. Atherton. 2013. External gill motility and striated muscle presence in the embryos of anuran amphibians. Tissue and Cell 45: 61-67.

Rada, M., S. J. Sánchez-Pacheco, and A. A. VelásquezÁlvarez. 2007. Some considerations on the ex-situ management and care of glassfrog egg masses and tadpoles (Anura: Centrolenidae). Revista Academia Colombiana de Ciencias Exactus, Fisicas y Naturales 31: $167-170$.

Salazar-Nicholls, M. J. and E. M. Del Pino. 2014. Early development of the glass frogs Hyalinobatrachium fleischmanni and Espadarana callistomma (Anura: Centrolenidae) from cleavage to tadpole hatching. Amphibian and Reptile Conservation 8: 89-106.

Valencia-Aguilar, A., F. Castro-Herrera, and M. P. RamírezPinilla. 2012. Microhabitats for oviposition and male clutch attendance in Hyalinobatrachium aureoguttatum (Anura: Centrolenidae). Copeia 2012: 722-731.

Villa, J. 1984. Biology of a neotropical glass frog, Centrolenella fleischmanni (Boettger), with special reference to its frogfly associates. Contributions in Biology and Geology 55: 1-60.

Vockenhuber, E. A., W. Hödl, and U. Karpfen. 2008. Reproductive behaviour of the glass frog Hyalinobatrachium valerioi (Anura: Centrolenidae) at the tropical stream Quebrada Negra (La Gamba, Costa Rica). Stapfia 88: 335-348.

Vockenhuber, E. A., W. Hödl, and A. Amézquita. 2009. Glassy fathers do matter: egg attendance enhances embryonic survivorship in the glass frog Hyalinobatrachium valerioi. Journal of Herpetology 43: 340344.

Warkentin, K. M. 2011. Plasticity of hatching in amphibians: evolution, trade-offs, cues and mechanisms. Integrative and Comparative Biology 51: 111-127. 